\title{
Considerations on Improvement of Moving Properties of Cable-less Magnetic Micro-actuator
}

\author{
H. Yaguchi and H. Suzuki* \\ Tohoku Gakuin University, 1-13-1 Tagajo, Miyagi, Japan \\ * Furukawa NDK Corporation, 16-1, Shintakayachi, Sakuranome, Osaki, Miyagi, Japan
}

\begin{abstract}
This paper proposes a new cable-less magnetic micro-actuator that operates on the inertia force of a one-degree-of-freedom model by using electromagnetic force. It has optimal design for the inclination angle of the one-degree-of-freedom model and an appropriate selection of suction force at the actuator support. The mechanical dc-ac inverter incorporates a cantilever beam and the one-degree-of-freedom model that switches under electromagnetic force. The volume of the prototype cable-less micro-actuator with three dry cells was about $1.5 \mathrm{~cm}^{3}$. Our experimental results revealed that the actuator could move vertically at $18.8 \mathrm{~mm} / \mathrm{s}$ when the duty ratio of the produced voltage was $46.2 \%$. The operating time for a duty ratio of $26.5 \%$ was 36 min, providing a total operating range of $26 \mathrm{~m}$ for horizontal travel or $15.5 \mathrm{~m}$ for vertical travel. The actuator has many possible applications in small pipe inspections, repairs, and machining because it can move on magnetic substances.
\end{abstract}

Key words: magnetic micro actuator, cable-less, long-distance movement, optimal design, mechanical dc-ac inverter

\section{ケーブルレス型磁気マイクロアクチュエータの走行特性改善に関する考察}

\section{矢口博之・鈴木 裕之*}

東北学院大学工学部，多賀城市中央 1丁目 13-1（广985-8537）

*古川 NDK 株式会社，大崎市桜ノ目字新高谷地 16-1（†989-6233）

\section{1. はじめに}

産業分野においては，人間の手の届かない微小領域や環 境の劣悪な状況下での点検や作業，医療分野においては， 体内での検査や治療を行うマイクロロボットの出現が望ま れている. 近年, 様々な原理により動作するマイクロロボ ットに関する研究 ${ }^{1) \sim 3)}$ が行われ，原子炉管内を探索する マイクロロボット ${ }^{4)}$ や, 部品の精密測定あるいは微細加工 等を行う作業用マイクロロボット5)，6）などが提案されて いる. 筆者も前報 ${ }^{7)}$ において, 電源部を含夕約 $1.5 \mathrm{~cm}^{3}$ 程度 の容積で, 自走可能なケーブルレス型磁気マイクロアクチ ユエータを提案し，動作原理および走行特性を明らかにし た。本アクチュエータは, 搭載された機械式DC-ACインバ ータにより振動体を共振させ，発生する慣性力を利用して 走行するもので, 高い推進性能を発揮する.

本研究では, 前報 7 ) で提案したアクチュエータの更なる 高出力化および長距離走行化を図ることを目的としている アクチュエータ走行上における適切なパラメータの選定お よび振動体の傾き角に関しての最適設計の結果を踏まえて アクチュエータを試作し，その走行特性を調べた。さらに 長距離走行させるために，機械式DC-AC インバータで生 成される方形波電圧のDuty比を小さくして, ボタン電池の 発生電流をなるべく抑えて走行させる手法を示した。これ より前報 ${ }^{7)}$ に比べ, 走行速度を低下させることなく, 移動 距離を約 3 倍増加させている.

本アクチュエータは, 磁性体の走行レールを設定すると,
制御装置を搭載すること無く，任意形状のレールに沿って 自在に移動可能であるという特徵を有する。本報告におい て得られた動作時間および走行距離を考慮すると，管内を 走行して検査するマイクロロボットや, 磁性体の天井など に貼りついて走行する，観賞用アミューズメントマシンな どへの拡張が考えられる。

\section{2. ケーブルレス型磁気マイクロアクチュエータ}

\section{1 アクチュエータの構造}

Fig.1(a)，(b)に，本研究で試作されたケーブルレス型磁気 マイクロアクチュエータの構造を示す．本アクチュエータ は，振動体を構成する 1 個の並進ばねおよび永久磁石，励 磁用電磁石, アクチュエータ支持部に接着された永久磁石, 先端部に銅電極を有する片持はり，3 個のボタン型酸化銀 電池により構成される.用いた並進ばねは, 自由長さ $6 \mathrm{~mm}$,

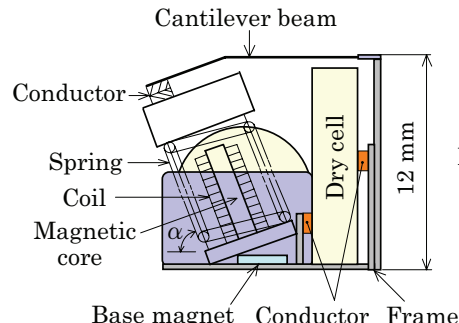

(a) Front view

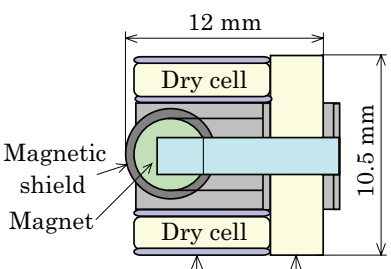

Dry cell box Dry cell

Fig. 1 Structure of micro-actuator. 
Table 1 Properties of spring.

\begin{tabular}{|c|c|c|}
\hline Material & $\begin{array}{c}\text { Spring } \\
\text { constant (N/m) }\end{array}$ & $\begin{array}{c}\text { Diameter of wire } \\
(\mathrm{mm})\end{array}$ \\
\hline SUS304 & 880 & 0.5 \\
\hline
\end{tabular}

Table 2 Magnetic properties.

\begin{tabular}{|c|c|c|}
\hline Material & $\begin{array}{c}\text { Magnetic flux } \\
\text { density }(\mathrm{mT})\end{array}$ & $\begin{array}{c}\text { Dimensions } \\
(\mathrm{mm})\end{array}$ \\
\hline $\mathrm{NdFeB}$ & 380 & $\varphi 5 \times 3$ \\
\hline
\end{tabular}

Table 3 Properties of electromagnet.

\begin{tabular}{|c|c|c|}
\hline $\begin{array}{c}\text { Material } \\
\text { of yoke }\end{array}$ & $\begin{array}{c}\text { Number } \\
\text { of turns }\end{array}$ & $\begin{array}{c}\text { Electric resistance } \\
(\Omega)\end{array}$ \\
\hline Mild steel & 1000 & 47 \\
\hline
\end{tabular}

外径 $5 \mathrm{~mm}$ のステンレス鋼製圧縮コイルばねである。永久 磁石としては円柱形で，厚さ方向に着磁された $\mathrm{NdFeB}$ 磁 石を用いた. 励磁用電磁石は長さ $5.2 \mathrm{~mm}$, 直径 $1.5 \mathrm{~mm}$ の 軟鋼材に直径 $0.07 \mathrm{~mm}$ の銅線を巻いて作製した。圧縮コイ ルばね, 永久磁石, 電磁石の緒元をそれぞれTable1 から Table 3 に示寸.また永久磁石は, 外径 $5.5 \mathrm{~mm}$, 内径 $5 \mathrm{~mm}$, 厚さ $3 \mathrm{~mm}$ の鋼製円筒材で磁気的にシールドされ, 電池への 吸引力を低減している。この電磁石をばね一永久磁石によ り構成される 1 自由度振動モデル内に挿入した. 永久磁石 と電磁石の鉄心との空隙は $1.2 \mathrm{~mm}$ である. 振動体は, アク チュエータ支持部の水平面から角度 $\alpha=47^{\circ}$ で傾けて固定 してある。また支持部には直径 $6 \mathrm{~mm}$ ，厚さ $0.6 \mathrm{~mm}$ で，厚 さ方向に着磁された, 表面磁束密度 $150 \mathrm{mT}$ T $\mathrm{SmCO}_{5}$ 磁石 が接着されている. 用いた片持はり材はアクリル製で，は り先端部に接着された銅電極と, 永久磁石上に取付けられ た銅電極との間には初期接触力が加えられている。なお, アクリルはり支持部のフレームを折り曲げることにより， 両振動体間の初期接触力を可変することができる.

\section{2 アクチュエータの推進速度および数值計算例}

Fig.2(a)に示す振動体は，圧縮コイルばねのばね定数を $k$, ばね材の粘性減衰係数を $C$, 永久磁石の質量を $m$ とし て, Fig.2(b)に示す 1 自由度振動モデルに置換えることがで きる. 電磁石により質量 $m$ が強制調和加振力 $R \sin \omega t$ を受

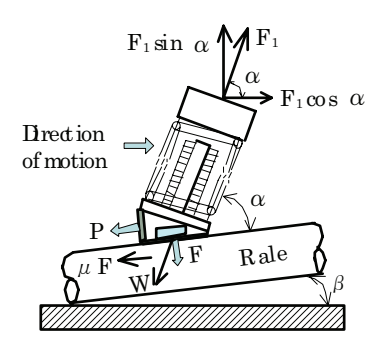

(a) Vibration body

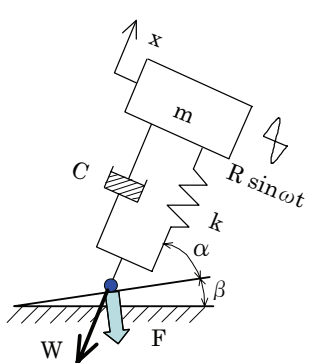

(b) Equivalent model
Fig. 2 One-degree-of-freedom model.
けるとき，モデルの運動方程式は次のように表される.

$$
m \frac{d^{2} x}{d t^{2}}+C \frac{d x}{d t}+k x=R \sin \omega t
$$

式(1)の解は， $A$ を変位振幅, $\theta$ を位相とすると次式となる.

$$
\left.\begin{array}{l}
x=A \sin (\omega t-\theta), p=\sqrt{k / m}, \theta=\frac{2 \zeta(\omega / p)}{p^{2}-\omega^{2}} \\
A=\frac{R / k}{\sqrt{\left(1-\omega^{2} / p^{2}\right)^{2}+\left(2 \zeta \omega^{2} / p^{2}\right)^{2}}}, \zeta=\frac{C}{2 m p}
\end{array}\right\}
$$

本アクチュエータを磁性体上に置くと, 支持部永久磁石に よりアクチュエータの支持台は吸引力 $F$ を受ける. 質量 $m$ が変位 $\boldsymbol{X}$ で調和振動するとき, アクチュエータの支持台に作 用する力振幅 $F_{m}$ およびその実効値 $F_{1}$ は

$$
\left.\begin{array}{c}
k x+C \frac{d x}{d t}=-m \frac{d^{2} x}{d t^{2}}=F_{m} \sin (\omega t-\theta+\phi) \\
F_{m}=A \sqrt{k^{2}+(C \omega)^{2}}, \tan \phi=c \omega / k, F_{1}=F_{m} / \sqrt{2}
\end{array}\right\}
$$

Fig.2 に示すように, $P$ を牽引力， $\alpha$ を振動体と走行レール とのなす角度, $\beta$ をアクチュエータ走行時におけるレールと 水平面との角度, $W$ をアクチュエータの自重, $\mu$ をアクチ ユエータのフレームと支持台との間の動摩擦係数とする.

1 自由度振動体を傾かせた方向, 寸なわち前方方向へアク チュエータがすべりはじめるときの, 水平方向の力のつり あいより次式が得られる.

$F_{1} \cos \alpha=\mu\left(F-F_{1} \sin \alpha+W \cos \beta\right)+W \sin \beta+P$

一方，後方方向へすべりはじめるときの力のつりあいより 次式が得られる.

$F_{1} \cos \alpha=\mu\left(F+F_{1} \sin \alpha+W \cos \beta\right)-W \sin \beta-P$

いま 1 自由度振動体において発生する弾性エネルギーの実 効值を $U$ とし, 式(4), (5)より 1 自由度振動体が 1 サイク ル間に移動する変位を求める. 振動体が座標 $\mathrm{x}$ 方向に振動し, 支持台に作用する引張力により生じる変位を前方推進変位 $\delta_{f}$, 振動体が座標 $\mathrm{x}$ とは逆方向に振動し, 支持台に作用す る圧縮力により生じる変位を後方推進変位 $\delta b$ とすると, こ れらは次のように表される.

$$
\left.\begin{array}{c}
\delta_{f}=\frac{(\bar{U}) \cos \alpha}{\mu\left(1-\bar{F}_{1} \sin \alpha+\bar{W} \cos \beta\right)+\bar{W} \sin \beta+\bar{P}} \\
\delta_{b}=\frac{(\bar{U}) \cos \alpha}{\mu\left(1+\bar{F}_{1} \sin \alpha+\bar{W} \cos \beta\right)-\bar{W} \sin \beta-\bar{P}} \\
\bar{F}_{1}=\frac{F_{1}}{F}, \bar{P}=\frac{P}{F}, \bar{U}=\frac{U}{F}, \bar{W}=\frac{W}{F}, U=\left(\frac{1}{2} k A^{2}\right) / \sqrt{2}
\end{array}\right\}
$$

となる. 式(7)で算出された変位 $\delta$ に, アクチュエータの駆 動振動数をかけると, 1 秒当たりの移動変位すなわち速度 を求めることができる。 またアクチュエータに作用させる 
率引力を無視し, 水平面上を走行させる場合, 振動体の最 適角度 $\alpha_{\text {opt }}$ は， $d \delta / d \alpha=0$ として次式から算出される.

$$
\alpha_{o p t}=\sin ^{-1}\left(\sqrt{\frac{1+2 \bar{W}+\bar{W}^{2}}{2\left(1+2 \bar{W}+\bar{W}^{2}\right)-\bar{F}_{1}^{2}}}\right)
$$

さて数值計算例について考える. Fig.3 は動摩擦係数 $\mu=0.2$, 振動体の傾き角度 $\alpha=60^{\circ} ， \bar{U}=0.1 \mathrm{~mm}$ に取り, $\bar{W}=0$ および $\beta=0$, すなわちアクチュエータの自重を 0 と して水平面を走行させた場合, 無次元負荷荷重 $\bar{P}$ とアクチ

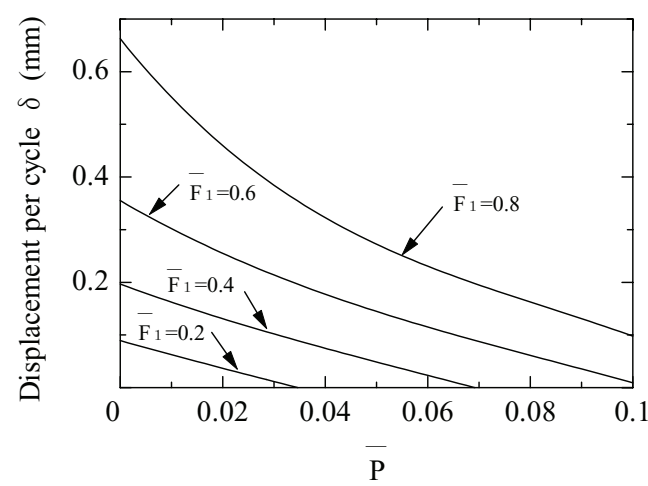

Fig. 3 Relationship between $\bar{P}$ and displacement per cycle.

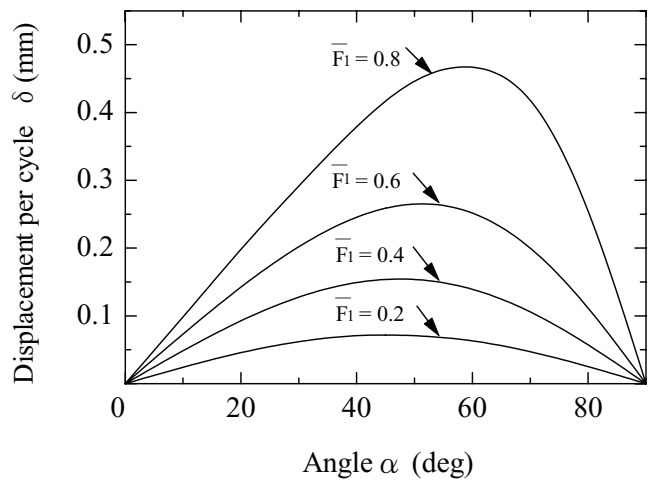

Fig. 4 Relationship between angle and displacement per cycle.

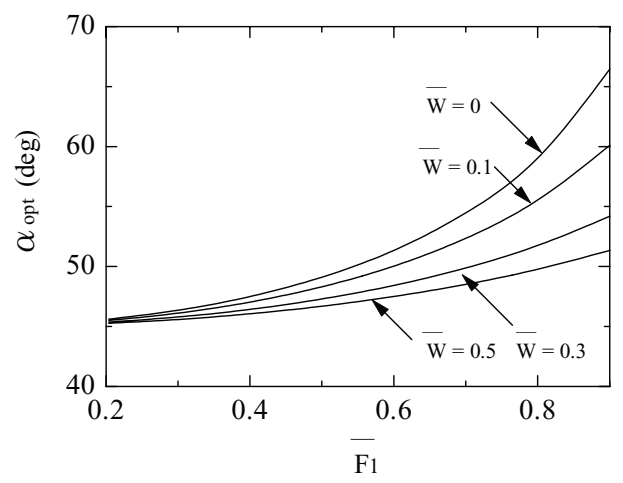

Fig. 5 Relationship between $\bar{F}_{1}$ and optimal angle.
ユエータ 1 サイクル当りの移動変位 $\delta$ との関係を, 力比 $\bar{F}_{1}$ をパラメータとして示したものである。 $\bar{F}_{1}$ が大，すなわち 振動体で発生する力 $F_{1}$ を大, あるいは支持部吸引力 $F$ を小 する程, 走行速度は大となる. 図より $\bar{F}_{1}$ の值は, アクチュ エータの走行特性におよぼす影響が極めて大きいことから, アクチュエータを設計する上で, 吸引力 $F$ の選定は最も重要 なものの一つと考えられる. Fig. 4 は $\mu=0.2, \beta=0, \bar{W}=0$, $\bar{P}=0, \bar{U}=0.1 \mathrm{~mm}$ に取り, $\alpha$ と $\delta$ との関係を, 各種の $\bar{F}_{1}$ に 対して示したものである. 図より各 $\bar{F}_{1}$ に対して, アクチュ エータの走行速度を極大にする最適な振動体の傾き角度 $\alpha_{\text {opt }}$ 名存在するのが分かる. Fig. 5 は $\mu=0.2, \beta=0, \bar{P}=0$, $\bar{U}=0.1 \mathrm{~mm}$ に取り, $\bar{F}_{1}$ と $\alpha_{\text {opt }}$ との関係を, 各 $\bar{W}$ について示 したものである。 $\alpha_{\text {opt }}$ は $\bar{F}_{1}$ が増加するに従い大となる。ま たFig.4 およびFig.5の結果より， $\bar{W}$ および $\bar{F}_{1}$ の各種パラ メータを変化させても, 振動体の最適傾き角 $\alpha_{o p t}$ は, ほぼ $45^{\circ} \sim 60^{\circ}$ の範囲内にあることが分かる.

\section{31 自由度振動体の走行特性}

ケーブルレス型アクチュエータ試作の前に, 1 自由度振 動体の走行特性を, Fig.6 に示すように発信器およびアンプ を用い，外部よりケーブル駆動して測定した１ 1 自由度振 動体は, Fig.1 に示寸振動体と同じ緒元で, 永久磁石部のシ ールド材が無い構造である。また振動体の傾き角 $\alpha=60^{\circ}$ とし, 共振振動数 $\mathrm{f}=180 \mathrm{~Hz}$, モデルの質量は $1.2 \mathrm{~g}$ である. この振動体を Fig.6 に示すように, 幅 $8 \mathrm{~mm}$, 厚さ $10 \mathrm{~mm}$

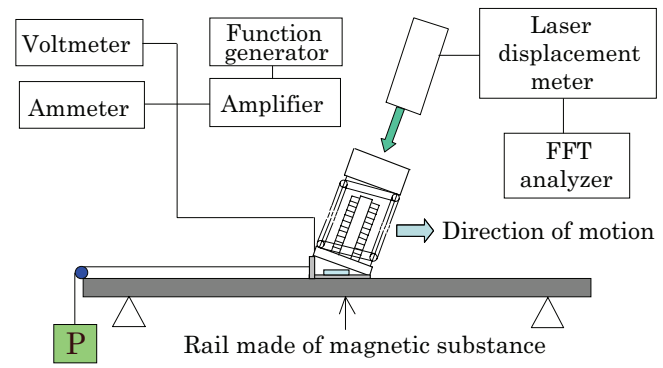

Fig. 6 Experimental apparatus.

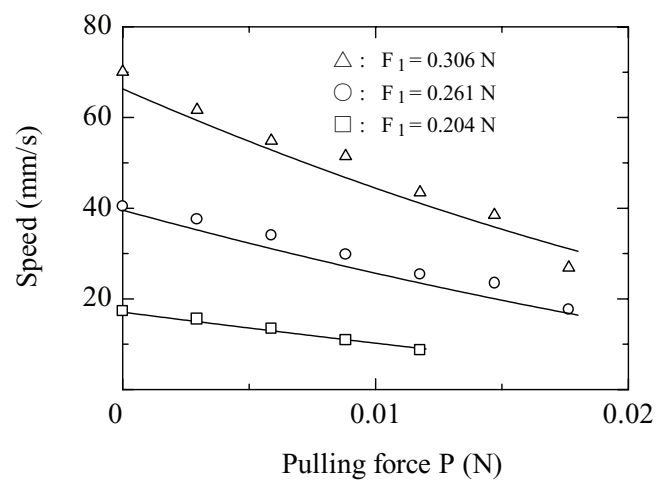

Fig. 7 Relationship between pulling force and speed $(F=0.377 \mathrm{~N}, \quad \beta=0)$. 
のまっすぐな軟鋼材レール上に設置し，振動体支持部の吸 引力 $F$, 振動体支持台に作用する力 $F_{1}$, アクチュエータに 牽引させる荷重 $P$ 変化させ, その走行速度を測定した。 支持台とアクリル材との間の動摩擦係数 $\mu=0.23$ である.

Fig.7 は， $F=0.377 \mathrm{~N}$ 取り， $F_{1}$ をパラメータとして, 負 荷荷重と水平面上での走行速度との関係を示したものであ る. 支持台に作用する力振幅の実効值 $F_{1}$ については, レー ザ変位計とFFTアナライザを用いて, 走行中の振動体永久 磁石の振動振幅 $A$ を計測し, ばね材の減衰の影響は小とし て無視し， $F_{1}=k A / \sqrt{2}$ より算出している.また自重の影響 を考慮し, 式(7)より算出された理論的な移動速度を実線で 示す. 計算值と実験值は, 概ね一致しているのが分かる.

\section{3. ケーブルレス型マイクロアクチュエータの走行特性}

本マイクロアクチュエータに搭載する電源はボタン電池 などの直流電源であるため, これを交流電源に変換する必 要がある. 前報 ${ }^{7)}$ において, 2 つの振動体の接触動作を利 用した機械式DC-ACインバータを提案し, その動作振動数 帯域および両振動体間の初期接触力による生成交流電圧の 変化について考察した。本報告においても, 前報において 得られた結果を踏まえ, Fig.1に示すように, 1 自由度振動 体と振動体上部に取付けられた銅電極および先端部に銅電 極を有する片持はりによりDC-ACインバータを構成し，ケ ーブルレス型アクチュエータを試作した。用いたはりはア クリル製で, 寸法は長さ $9 \mathrm{~mm}$, 幅 $3 \mathrm{~mm}$, 厚さ $0.1 \mathrm{~mm}$ であ る. さらに片持はり先端部には, 長さ $2 \mathrm{~mm}$, 幅 $3 \mathrm{~mm}$, 厚 さ $0.2 \mathrm{~mm}$ の銅製電極が取付けられており, 系の固有振動数 は $95 \mathrm{~Hz}$ である.これらアクリルはりの寸法をFig. 8 に示す. アクチュエータを駆動する電池としては，マクセル社製 SR920Wボタン型酸化銀電池を 3 個用いた. その緒元は, 外形 $9.5 \mathrm{~mm}$, 厚さ $2.05 \mathrm{~mm}$, 質量 $0.6 \mathrm{~g}$, 公称電圧 $1.55 \mathrm{~V}$, 電池容量 $39 \mathrm{mAh}$ であり, これらの電池は電池ボックスに取 付けられている. これよりアクチュエータの寸法は, 全長 $12 \mathrm{~mm}$, 全高 $12 \mathrm{~mm}$, 全幅 $10.5 \mathrm{~mm}$ で, 総容積は $1.5 \mathrm{~cm}^{3}$, 総質量は $3 \mathrm{~g}$ となる.

さて先の数值計算例にも示したように, アクチュエータ

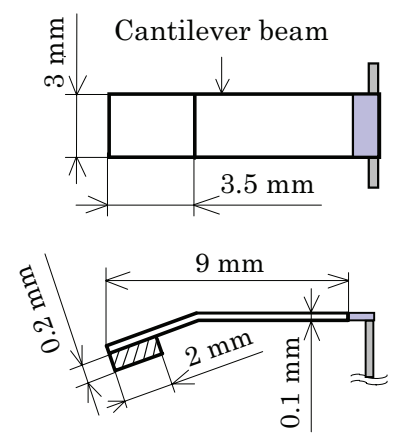

Fig. 8 Dimensions of cantilever beam.
の走行特性は，支持部吸引力 $F$ によて大きく左右される. 本報告では，自重が大きくても垂直上昇走行が可能で，か つ水平面上においても適度な速度で走行が可能であると想 定して $F=0.85 \mathrm{~N}$, 振動体の傾き角度は $\alpha=47^{\circ}$ に, アク チュエータと磁性体面との動摩擦係数 $\mu=0.3$ に設定した. なお自重の影響を考慮して $\bar{W}=0.035 ， \mu=0.3$ とし, $\bar{F}_{1}=0.35$ と仮定して水平面上を走行させる場合, 理論的な 振動体の最適傾き角度 $\alpha_{o p t} \fallingdotseq 47^{\circ}$ となる.

試作したアクチュエータにおいて，はり支持部のフレー ムを折り曲げて, 両振動体間の初期接触力を変化させ, 走 行速度を測定する. 測定では試作されたアクチュエータを 幅 $8 \mathrm{~mm}$, 厚さ $10 \mathrm{~mm}$ のまっすぐな軟鋼レール上に置き, コイルを用いて, 1 自由度振動体の固有振動数 $\mathrm{f}=135 \mathrm{~Hz}$ に同調した調和加振力を加えて振動体を起動し，アクチュ エータを走行させた. Fig.9 は両振動体間の初期接触力 $T$, すなわち生成方形波電圧の Duty 比を変化させた場合の, レールの傾き角度 $\beta$ と移動速度との関係を示したものであ る.また初期接触力を変化させて測定した, 生成方形波電

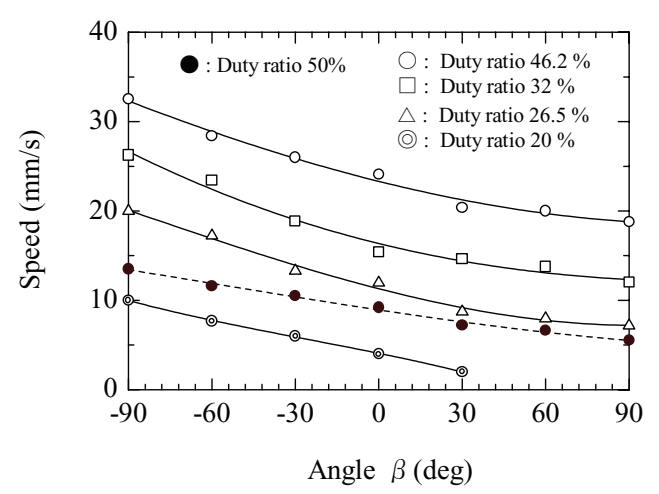

Fig. 9 Relationship between angle of rail and speed $\left(\alpha=47^{\circ}\right)$.

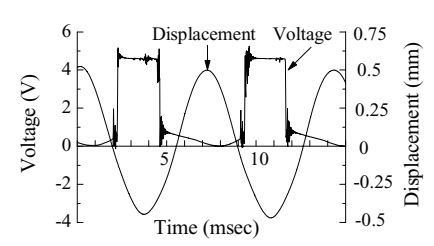

(a) Duty ratio $26.5 \%$ ( $T=1.50 \mathrm{mN})$

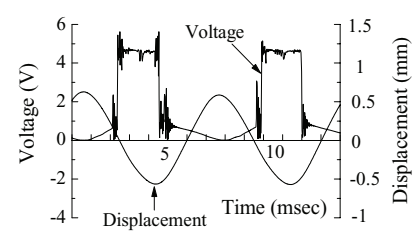

(b) Duty ration $32 \%$ $(T=2.40 \mathrm{mN})$

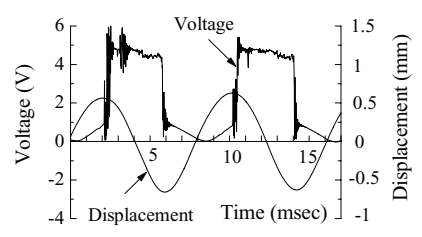

(c) Duty ratio $46.2 \%(T=3.42 \mathrm{mN})$

Fig. 10 Displacement of $\mathrm{m}^{-\mathrm{k}}$ model and produced voltage. 
Table 4 Duration and distance of motion.

\begin{tabular}{|c|c|c|c|}
\hline $\begin{array}{c}\text { Duty ratio } \\
(\%)\end{array}$ & $\begin{array}{c}\text { Motion } \\
\text { time (min) }\end{array}$ & $\begin{array}{c}\text { Horizontal } \\
(\mathrm{m})\end{array}$ & $\begin{array}{c}\text { Vertical } \\
(\mathrm{m})\end{array}$ \\
\hline 26.5 & 36 & 25.9 & 15.5 \\
\hline 32 & 20 & 18.5 & 14.4 \\
\hline 46.2 & 11 & 15.9 & 12.4 \\
\hline
\end{tabular}

圧と振動体永久磁石部の振動変位を Fig.10 に示す. Fig.9 においてDuty比が大のほど, 走行速度は増加し, Duty比が $46.2 \%$ の場合, その水平移動速度は $24.1 \mathrm{~mm} / \mathrm{s}$, 垂直上昇速 度は $18.8 \mathrm{~mm} / \mathrm{s}$ であり, かなりの高速走行が可能となる。 前報 ${ }^{7)}$ において, $\alpha=50^{\circ}$, 生成方形波電圧のDuty比を約 $50 \%, F=0.65 \mathrm{~N}$ とた場合, ボタン電池 2 個搭載したモデ ルの結果を, ○印を用いて示す. Table4 は, 生成方形波電 圧の各Duty比における連続動作時間を示したものである. 生成方形波電圧のDuty比が減少寸るに従い，連続動作時間 は急激に増大するのが分かる. Duty比が $26.5 \%$ の場合, そ の動作時間は約 36 分である. 水平移動速度が $11.97 \mathrm{~mm} / \mathrm{s}$, 垂直上昇速度が $7.17 \mathrm{~mm} / \mathrm{s}$ であるため, 水平方向には $25.9 \mathrm{~m}$, 垂直方向には $15.5 \mathrm{~m}$ 移動可能となる.これは前報 ${ }^{7)}$ に比べ, 連続動作時間を約 2.3 倍, 走行距離を約 3 倍増加させたこ とになる.なお測定された振動変位を用いて $\bar{F}_{1}=0.35$ とし 式(7)より算出された理論的な走行速度は, Duty比が $26.5 \%$ の場合，水平方向において $13.6 \mathrm{~mm} / \mathrm{s}$, 垂直方向において $7.8 \mathrm{~mm} / \mathrm{s}$ となる。

\section{4. まとめ}

機械式 DC-AC インバータを有するケーブルレス型磁気 マイクロアクチュエータを試作し, 生成方形波電圧の Duty 比を変化させ，その走行特性を調べた。

数值計算の結果より，アクチュエータを設計する上にお いて, 吸引力 $F$ の選定は最も重要な項目の一つであること
を示し，ケーブル型アクチュエータの走行実験により数值 解の妥当性を検証した。適切な吸引力の選定を行い, 試作 されたアクチュエータにおいて, Duty 比が $46.2 \%$ の場合, 水平移動速度は $24.1 \mathrm{~mm} / \mathrm{s}$, 垂直上昇速度は $18.8 \mathrm{~mm} / \mathrm{s}$ で, かなりの高速走行が可能であることを示した。一方，長距 離走行させるために, 発生電圧のDuty比を小さくしてボタ ン電池の発生電流をなるべく抑え，比較的低速度にて走行 させる手法を示した．Duty比を $26.5 \%$ に選定すると，連続 動作時間は約 36 分で，水平移動速度は $11.97 \mathrm{~mm} / \mathrm{s}$, 垂直 上昇速度は $7.17 \mathrm{~mm} / \mathrm{s}$ である。これより水平方向には約 $26 \mathrm{~m}$, 垂直方向には $15.5 \mathrm{~m}$ 走行可能となる. 前報 ${ }^{7)}$ で得ら れた類似の実験結果に比べ，速度を低下させることなく連 続動作時間を約 2.3 倍, 走行距離を約 3 倍増加させること を示した，以上の結果より，本アクチュエータは，磁性体 のレールを設置すると, 垂直面および天井面の移動が可能 であるため，工学分野のみならず磁性体の天井や垂直面に 貼りついて，ゆっくり走行する観賞用アミューズメントマ シンなどへの拡張も考えられる.

\section{References}

1) T.Fukuda, N.Mitsumoto, F.Arai, H.Matsuura :

Trans.J.Soc.Mec.Eng., 56, 562 (1993).

2) K.Yamamoto, H.Otaki, Y.Ishikawa : Trans.J.Soc.Mec. Eng., 57, 538 (1991).

3) T.Higuchi, Y.Yamagata : J.Jpn.Soc.Prec.Eng., 58, 10 (1992). 4) K.Tsuruta, T.Shibata, N.Mitsumoto, T.Sasaya, M.Kawahara : Trans. IEE Jpn., 122, 2 (2002).

5) M.Suzuki, Y.Yamada, N.Tsuchida, K.Imai :

J.Jpn.Soc.Prec.Eng., 60, 1 (1994).

6) H.Aoyama, H.Kato : J.Jpn.Soc.Prec.Eng., 64, 12 (1998).

7) H. Yaguch: Trans. Magn. Soc. Jpn., 30, 2 (2006).

2006 年 10 月 21 日受理, 2007 年 1 月 23 日採録 